\title{
Towards a Populist Local Democracy? The Consequences of Populist Radical Right Local Government Leadership in Western Europe
}

\section{Fred Paxton}

To cite this article: Fred Paxton (2019): Towards a Populist Local Democracy? The

Consequences of Populist Radical Right Local Government Leadership in Western Europe,

Representation, DOI: 10.1080/00344893.2019.1643771

To link to this article: https://doi.org/10.1080/00344893.2019.1643771 


\title{
Towards a Populist Local Democracy? The Consequences of Populist Radical Right Local Government Leadership in Western Europe
}

Fred Paxton

Department of Social and Political Scienes, European University Institute, Florence, Italy

\begin{abstract}
A crisis of representation has precipitated a surge in support for populist radical right (PRR) parties that challenge the existing model of representative democracy.

Simultaneously, institutional reforms across Western Europe have sought to improve the input legitimacy of local democracy with a proliferation of direct and participatory democratic methods. This paper investigates the extent to which PRR parties advance a populist democratic agenda when in leadership of the executive at the local level of government. Previous work on the subject of PRR parties in power has neglected the sub-national perspective, despite the increasing congruence between populist demands for a more direct linkage of politics to the people and this institutional environment. An exploration of three cases of PRR party-led local government in Italy, Austria and Switzerland enables a comparison of their governing behaviour, its ideological content and democratic consequences, through qualitative content analysis of referendums, policies and council resolutions. This paper finds they do little to promote popular sovereignty through participatory forms of governance at the expense of representative democracy in local government. However, when in local government environments with higher executive autonomy, PRR parties emphasise a more direct (plebiscitarian) linkage between the executive and the 'people', who are increasingly represented in nativist terms.
\end{abstract}

KEYWORDS

Populism; radical right; local government; patterns of democracy; direct democracy 


\section{Introduction}

The belief that politics should be an expression of the sovereignty of the people, unrestricted and unmediated by elite institutions of representative democracy, is central to the now dominant ideological definition of populism (Mudde, 2004, p. 543). As a result, populist parties tend to focus upon defining 'the people' and advocate for the elevation of their authority in relation to elected representatives (Canovan, 1999; Kaltwasser, 2014; Meny \& Surel, 2002, p. 13; Mudde, 2007, pp. 150-155). The opportunity to actually implement this rhetoric has widened at the local level of government in particular. Concurrent with the surge of support for PRR parties in Western Europe since the 1980s, widespread reforms have expanded direct and participatory democratic methods (Caulfield \& Larsen, 2002; Kersting \& Vetter, 2003; Scarrow, 2003; Schiller, 2017). Subnational government not only acts as a 'laboratory' for institutional reform, it is also an arena in which parties can test policy (Egner, Gendźwiłł, Swianiewicz, \& Pleschberger, 2018, p. 329; Hendriks, Loughlin, \& Lidström, 2010). ${ }^{1}$ The local government perspective taken by this article is therefore the arena in which we would most likely witness the implementation of this core set of populist demands. Analyses of populist parties in power enable an expanded perspective on their ideology. The transition from opposition to government necessitates changes in strategy and corresponding discourse, and more constrained prioritisation among competing aims (Albertazzi \& Mcdonnell, 2005; Castanho Silva, 2017; Zaslove, 2012). However, the actions of PRR parties in power at the local level of government is an under-explored area, despite there being many more cases open to study. This article explores whether and how PRR parties utilise the particular opportunities of local government to apply their democratic ideals, and asks the following research question:

To what extent do PRR parties implement a populist democratic agenda when in power at the local level of government in different Western European countries?

The structure of the article is as follows. First I explore the ambiguous theoretical relationship between PRR ideology and representative democracy through the contested notions of a populist (radical right) democratic agenda. I conceptualise the populist democratic agenda to comprise a plebiscitarian, rather than representative, ideal of democracy and a nativist, rather than pluralist, definition of 'the people'. I then outline the various patterns of local democracy in Western Europe following significant reforms in recent decades. Systems are distinguished according to the autonomy of the local executive in two respects: following Lijphart (2012), the extent to which, firstly, they are majoritarian rather than consensual forms of democracy, and secondly, the direct democracy capability of the local executive. The paper then explores three cases of PRR party-led local government in Austria, Italy and Switzerland in the 2010s to make a comparison of their governing practice - specifically, their implementation of elements of a populist democratic agenda - in different institutional settings. The data analysed are local government initiated referendums, policies and interactions with the council. The findings demonstrate how the opportunity structures provided by varying cross-national patterns of local democracy influence the extent to which a distinctive idea of popular 
sovereignty and definition of 'the people' are expressed. Firstly, this study finds that PRR parties in all three cases do not implement an expansion of participatory governance, despite variations in the opportunity to do so. However the cases vary in the extent to which, secondly, the linkage between PRR executive actors and local citizens is envisaged in more plebiscitarian terms, and thirdly, an emphasis is placed upon an ethnic definition of 'the people' through nativist policy. These changes are more evident in the Italian case than the Austrian and, least of all, Swiss cases due to the varying degree of constraint imposed by power sharing with other parties. Finally, I conclude with a discussion of the implications for future research into the consequences of populism for representative democracy and hypotheses herein generated for future comparative studies of populist parties in (local) government.

\section{The Democratic Agenda of the Populist Radical Right}

In this section, I address the idea of a 'populist democratic agenda' and its expected programmatic components. The populist surge that has taken place in Western Europe in recent decades is rooted in a 'crisis of representation' to which they offer a distinctive response (Mair, 2002, p. 88). According to the dominant ideological approach, populism is a 'thin' ideology which is combined with other 'thicker' ideological elements to provide substantive demands and a coherent political project. In the case of the PRR, the core element is nativism. Populists conceive society as split into two internally homogenous and antagonistic camps - the virtuous people and the corrupt elite - and argue for the sovereignty of the people unmediated and unrestricted by representative institutions (Albertazzi \& McDonnell, 2008, p. 8; Canovan, 1999, p. 3; Laclau, 1977, pp. 172-173; Mudde, 2004, p. 543; Stanley, 2008; Urbinati, 2014, pp. 131, 151). This latter element is crucial to their promise of a different vision of democracy (Meny \& Surel, 2002, p. 11f; Mudde, 2004; Urbinati, 2014, p. 150). The relationship between populism and representative democracy is one of ambivalence. While populists presents a challenge to its functioning, they also use its institutions to champion the virtues of representation, albeit in a more direct form (Taggart, 2004, p. 278).

Prior to the question of whether and how PRR parties promote a distinctively populist democratic agenda in government, the very nature of such an agenda is a hotly contested topic. There are different ways to conceptualise the populist challenge to representative democracy, in terms of the idealised form of interaction, or linkage, between citizens and parties in government. One is a participatory linkage. With politics conceived ideally as an expression of the 'general will', a 'delegate' as opposed to 'trustee' style of political representation is favoured (Pitkin, 1967). Politicians should above all be responsive to, and act in congruence with, citizen preferences, rather than act as representatives free to interpret them (Caramani, 2017; Shills, 1956, p. 102). The ideal may take a concrete form in calls for the expansion of new forms of democracy to transmit the general will more directly (Kaltwasser, 2014, p. 479; Mudde \& Kaltwasser, 2013, p. 163;

Pauwels, 2014, p. 159). Participatory and deliberative methods provide opportunities to weaken the existing representative linkage through the empowerment of citizens, anda more active form of popular involvement than present in representative democracy (Bobbio, 2003). If we are to consider unrestricted popular sovereignty a core element of 
the ideological definition of populism, we could therefore expect them to attempt to act upon these ideals in government: to behave responsively as delegates and utilise new forms of governance that challenge the representative status quo.

However, the populist ideal of unmediated sovereignty of the people does not necessarily mean rule by the people. A form of linkage that contrasts with the participatory ideal is that of a plebiscitarian character (Barney \& Laycock, 1999; Barr, 2009). While similar to the participatory linkage in its pursuit of a more direct connection between citizens and government, a plebiscitarian linkage differs in its failure to grant citizens control over the process. According to this interpretation, populist actors tend to act as the embodiment and more efficient executors of the general will, rather than facilitators of citizens to truly govern themselves (Canovan, 2002, p. 34). We should therefore not expect the expansion of direct and participatory forms of democracy to be so central to populist attempts to foster the circumvention of the rule of 'elite' representatives and institutions by the 'will of the people'. While they can be a crucial means of influence for populist parties in opposition, populists in power have access to other means with which to achieve their goals: for instance through personalised politics and plebiscitary means (Canovan, 1999, p. 6; Mudde, 2007). There is, therefore, said to be an inherent tension between the more direct, even personal, populist representative ideal and the democratic aspirations therein embodied (Canovan, 1999, p. 14). Yet populist radical right voters in particular tend to in fact be more interested in the improved output of representative democracy than in the expansion of participatory forms of democratic input (Bowler, Denemark, Donovan, \& Mcdonnell, 2016; Webb, 2013, p. 771). ${ }^{2}$ Direct forms of democracy could therefore be considered as a tool used strategically by PRR actors to the extent that they facilitate the implementation of higher priority ideological concerns, rather than citizen participation being an ideological concern in and of itself.

The notion of popular sovereignty - fundamental to democracy in general and emphasised by populists in particular - leaves 'the people' undefined (Kaltwasser, 2014; Whelan, 1983). Three possible populist conceptions of 'the people' have been identified by Meny and Surel (2000): a political one (the people as sovereign), a cultural one (the people as native) and an economic one (the people as a class). The nativist ideology of the PRR leads to its characterisation by them as an ethno-culturally homogenous group. ${ }^{3}$ Due to their re-definition of demos as ethnos, PRR parties in the government threaten a transformation from the existing form of liberal democracy towards an ethnocracy with resulting harm to minority rights (Minkenberg, 2001). The relatively few existing studies of PRR parties in local power have focused upon their exclusionary impact in particular areas of policy: notably, immigration and integration (Bolin, Lidén, \& Nyhlén, 2014; Van Ostaijen \& Scholten, 2014), and cultural policy (Almeida, 2017). However insufficient attention has been paid to their relative emphasis on cultural-nativist and politicalsovereign definitions of 'the people', and the moderating force of structural factors from a comparative perspective. ${ }^{4}$ The influence of party ideology is expected to be greater in local government contexts with a stronger culture of partisanship and greater executive autonomy (DiGaetano \& Strom, 2003; Schmidt, 1996). According to the hierarchy within the ideological conception of populism, the host radical right ideology should be more clearly evident when facilitated by contexts of greater autonomy, to a greater extent than the 'thin' populism (Mudde, 2007; Pauwels, 2014, p. 21). 


\section{Direct Democratic Reforms and Patterns of Local Democracy}

The legitimacy of local representative democracy has been widely perceived to be in crisis in recent decades (Copus, 2003, p. 120; Kersting \& Vetter, 2003; Magnier, 2005; WilksHeeg, 2010, p. 382). ${ }^{5}$ All Western European countries have formally agreed to strengthen local autonomy and popular participation in response (Council of Europe, 1985), yet the extent to which this intention has been implemented via institutional reforms varies greatly. As a result, a range of institutional settings provide different opportunity structures for European PRR actors to advance a new democratic agenda while in local government. Local government input-legitimacy has been addressed through institutional reforms to widen the inclusiveness of preferences through an expansion of direct democratic control. ${ }^{6}$ The authority of local political leaders has been enhanced with the introduction of directly elected mayors in place of collegial forms of government (John, 2001, pp. 16-17). In addition, participatory governance techniques, including local referendums, have become more readily available (Council of Europe, 1993; Scarrow, 2001; Schiller, 2011). A summary of the distribution of these instruments for direct democratic control across Western European local governments is shown in Table 1. The reforms have reshaped the form of local democracy in these countries, in terms of the degree to which they can be characterised, following Lijphart (2012), as consensual or majoritarian in nature, due to their effect on the autonomy of the executive. Reforms that have introduced direct mayoral elections and the expansion of their power for example in Italy and most regions of Austria - have strengthened the relative position of the mayor and caused a shift from a 'committee-leader' towards a 'strong-mayor' form of local government (Mouritzen \& Svara, 2002).

Table 1. Direct democracy in Western European local government.

\begin{tabular}{lll}
\hline Elected mayors & Council-elected mayor \\
\hline $\begin{array}{l}\text { Directly elected mayor } \\
\text { Switzerland }\end{array}$ & $\begin{array}{c}\text { Not council-elected nor } \\
\text { directly elected mayor } \\
\text { Belgium, Finland, } \\
\text { Luxembourg, Netherlands, } \\
\text { Nocal referendums }\end{array}$ & $\begin{array}{c}\text { Denmark, France, Ireland, Malta, } \\
\text { Portugal, Spain, UK }\end{array}$ \\
$\begin{array}{l}\text { Popular initiatives and government } \\
\text { initiated referendums institutionalised } \\
\text { and frequently used }\end{array}$ & $\begin{array}{c}\text { Government initiated referendums } \\
\text { fairly common }\end{array}$ & $\begin{array}{c}\text { Referendums recently } \\
\text { institutionalised / rarely used }\end{array}$ \\
$\begin{array}{l}\text { Austria, Germany, Switzerland } \\
\text { Belgium, Denmark, Finland, Italy, } \\
\text { Luxembourg, Netherlands, Norway, } \\
\text { Spain, Sweden }\end{array}$ & $\begin{array}{c}\text { Cyprus, France, Greece, } \\
\text { Ireland, Malta, Portugal, UK }\end{array}$ \\
\hline
\end{tabular}

Source: Hendriks et al., 2010.

${ }^{\text {a}}$ Directly elected mayors have been introduced in a number of single and combined local authority areas of England in the 2000 s and 2010 s.

This study proposes two hypotheses regarding the implementation of a populist democratic agenda in local government, varying by the level of executive autonomy, as outlined in Table 2. The autonomy of the local executive is here considered in terms of the strength of majoritarian as opposed to consensual democracy, in particular regarding the constraints of power sharing with coalition partners, and itscapacity to initiate 
participatory and direct democratic measures. Firstly, in contexts that offer a higher level of autonomy to PRR parties in local government, they are expected to promote a plebiscitarian, rather than indirectly representative, form of democracy. Secondly, in such contexts they are expected to promote a nativist, rather than pluralist, definition of 'the people'.

Table 2. Hypothesised relation between local executive autonomy and democratic agenda promoted by PRR-led local government.

\begin{tabular}{|c|c|c|c|c|}
\hline \multicolumn{2}{|c|}{ Local executive autonomy } & \multicolumn{3}{|c|}{$\begin{array}{c}\text { Democratic agenda promoted by PRR-led local } \\
\text { government }\end{array}$} \\
\hline & locracy capacity & Democratic form & & $\begin{array}{l}\text { Definition of } \\
\text { 'the people' }\end{array}$ \\
\hline+ & + & Plebiscitarian & & Nativist ++ \\
\hline+ & - & $\begin{array}{l}\text { Representative } \\
\text { plebiscitarian elements }\end{array}$ & with & Nativist ++ \\
\hline- & + & $\begin{array}{l}\text { Representative } \\
\text { plebiscitarian elements }\end{array}$ & with & Nativist + \\
\hline- & - & Representative & & Pluralist \\
\hline
\end{tabular}

According to Lijphart (2012, p. 31) 'direct democracy cannot be regarded as either typically majoritarian or typically consensual'. Yet variants of direct democratic instruments that concentrate power, like government-initiated referendums, correspond more closely to majoritarian forms of democracy, while others like popular initiatives that diffuse power are closer to consensus democracy (Vatter, 2009; Vatter \& Bernauer, 2009). Lijphart's distinction between majoritarian and consensual democracies has been expanded upon by Hendriks (2010) to incorporate subnational democracy. In so doing he adds a second dimension regarding direct and indirect democracy, as this level presents a 'relatively fertile breeding ground for expressions of, and experiments with, direct democracy - more so than the national level' (Loughlin, Hendriks, \& Lidström, 2011, p. 19).

Existing cross-national comparisons of the use of direct democracy in local government have taken different approaches without considering the role of specific governing party ideologies. In general, the primary use of referendums comes from opposition and citizens rather than from governing parties (Bowler, Donovan, \& Karp, 2002). According to an institutionalist perspective, there will be more referendums used in local government contexts in which there is greater legal capacity for their implementation and a stronger communal tradition of their use (Bützer, 2007, p. 217; Hug, 2004). Furthermore, in a comparison between Swiss cantons, Vatter (2003) finds the less consensual character of the local democracy (i.e., the more majoritarian), the more referendums in general are used as a mechanism that compensates for the power of the executive. To instead consider government usage of referendums, a political-strategic perspective is helpful. Direct and participatory democracy provide tools to gain influence within policy processes, where power is otherwise lacking (Hug \& Tsebelis, 2002). Government actors may use referendums to strengthen their authority from a position of weakness, for example due to intraparty or intra-governmental tensions (Luthardt, 1994, p. 140; Smith, 2016). 
Political actors may also draw on the rhetoric of popular sovereignty and direct democracy as a form of symbolic representation (Pitkin, 1967), even if not necessarily executed in practice. Performance and claims-making are particularly important elements of political representation for populist actors, therefore the discourse and symbolic expression of populist actors is as crucial for studies of their government participation as in opposition (Moffitt \& Tormey, 2014; Saward, 2006). Existing analyses have identified the different populist definitions of 'the people' according to ideology (right and left), geography (Europe and South America) and time (for example, the discursive shift of radical right parties towards 'cultural differentialism' in recent decades) without consideration of particularities that may be found at the sub-national level.

\section{Research Design}

To assess these hypotheses, I conduct a comparative analysis of three cases of PRR party executive participation. The parties are selected from within a party family that is relatively homogenous in terms of ideological priorities and policy profile (Ennser, 2012; Ivarsflaten, 2008). As a result, we can explore the influence of the institutional context on the implementation of their common ideals through comparison of their governing actions in different settings. The institutional contexts of the cases selected vary according to the degree to which they are a consensual form of democracy and the resulting constraint of compromise imposed upon governing parties (Fallend, 2011; Hendriks, 2010; Lijphart, 2012). The adaptation of the consensual and opposed majoritarian models of democracy to the local level requires modification of the corresponding variables. The executiveparties dimension identifies the ease with which a single party can take control of the government, measured in this study across four variables. ${ }^{7}$ Firstly, the party system: whether two-or multi-party; secondly, the cabinet form: either a one-party concentration or a sharing of executive power with other parties; thirdly, the relations between the executive and legislative: whether the executive is dominant or power is balanced; and fourthly, the electoral system: whether majoritarian or proportional. The other federalunitary dimension is assessed through one relevant variable, to assess the extent to which a party in government can change policy. Through assessment of the degree of decentralisation, we can identify the corresponding level of functional competence and policy discretion allocated to the local level of government (Kersting \& Vetter, 2003, pp. 22-25; Mouritzen \& Svara, 2002). ${ }^{8}$ As shown in Table 3, a range in consensual democracy in terms of these criteria is provided by the selection of, from low to high: Italy, Austria and the Swiss canton of Bern.

The capacity of the local executive to initiate direct democracy also varies between these three contexts, as shown in Table 4. Citizens and opposition in all three settings can initiate referendums. In addition, the local executive in Austria can initiate referendums on issues within its competence, while in Italy and Switzerland the government may only introduce mandatory referendums on certain prescribed topics.

The cities are selected based on the senior position of a PRR party in the local government executive and occupation of the mayoralty. Larger cities were favoured, as a greater population size of the municipality tends to offer greater resources for parties to perform ideologically distinctive action. The cities selected are the largest to have been 
governed by the PRR in their respective countries in the current decade: Padua in Italy, Wels in Austria, and Thun in the Swiss canton of Bern. In Padua, the election of a Lega Nord mayor was a break with centre-left and - right party rule throughout the post-war period, while the election victories of the FPÖ in Wels and the SVP in Thun in 2014 and 2010 respectively led to the first PRR mayors following decades of social democratic rule. They therefore provide insight into the (mutual) impact of PRR parties in local government power for the first time. In a period when these parties seem increasingly likely to attain positions of power, these sub-national cases provide insights into their ideological priorities, made evident through the gap between rhetoric and government policy.

Table 3. Institutional setting of cases.

\begin{tabular}{|c|c|c|c|c|c|c|}
\hline & $\begin{array}{l}\text { Party } \\
\text { system }\end{array}$ & $\begin{array}{l}\text { Form of } \\
\text { cabinet }\end{array}$ & $\begin{array}{l}\text { Executive- } \\
\text { legislative } \\
\text { balance }\end{array}$ & $\begin{array}{l}\text { Electoral } \\
\text { system }\end{array}$ & $\begin{array}{c}\text { Level of } \\
\text { decentralisation }\end{array}$ & $\begin{array}{l}\text { Majoritarian } \\
\text { form of } \\
\text { democracy }\end{array}$ \\
\hline \multicolumn{2}{|c|}{$\begin{array}{l}\text { Padua, Italy } \\
\qquad \begin{array}{l}\text { Multi-party } \\
\text { Lega Nord mayor 2014-16. }\end{array}\end{array}$} & $\begin{array}{l}\text { Concentrated } \\
\text { chosen by } \\
\text { mayor }\end{array}$ & $\begin{array}{l}\text { Executive } \\
\text { dominant }\end{array}$ & $\begin{array}{l}\text { Council: PR } \\
\text { with } \\
\text { premium. } \\
\text { Mayor: } \\
\text { majority. }\end{array}$ & $\begin{array}{l}\text { Low federal and } \\
\text { unitary }\end{array}$ & + \\
\hline $\begin{array}{l}\text { Wels, Austria } \\
\text { FPÖ mayor } \\
2015-\text {. }\end{array}$ & $\begin{array}{l}\text { Multi- } \\
\text { party }\end{array}$ & $\begin{array}{l}\text { Multi-party } \\
\text { allocated } \\
\text { proportionally }\end{array}$ & $\begin{array}{l}\text { Executive } \\
\text { dominant }\end{array}$ & $\begin{array}{l}\text { Council and } \\
\text { executive: } \\
\text { PR. Mayor: } \\
\text { majority. }\end{array}$ & $\begin{array}{l}\text { Medium-low } \\
\text { federal and } \\
\text { centralised }\end{array}$ & $+/-$ \\
\hline \multirow{2}{*}{$\begin{array}{l}\text { Thun, } \\
\text { Switzerland } \\
\text { SVP mayor } \\
2010-\text {. }\end{array}$} & \multirow[t]{2}{*}{$\begin{array}{l}\text { Multi- } \\
\text { party }\end{array}$} & \multirow[t]{2}{*}{$\begin{array}{l}\text { Multi-party } \\
\text { allocated } \\
\text { proportionally }\end{array}$} & $\begin{array}{l}\text { Power balanced } \\
\text { PR. between } \\
\text { Execu }\end{array}$ & $\begin{array}{l}\text { Council: } \\
\text { utive: }\end{array}$ & \multirow[t]{2}{*}{$\begin{array}{l}\text { High federal and } \\
\text { decentralised }\end{array}$} & \multirow[t]{2}{*}{-} \\
\hline & & & $\begin{array}{c}\text { council and } \\
\text { executive }\end{array}$ & PR. & & \\
\hline
\end{tabular}

Source: Loughlin et al. (2011).

Table 4. Local direct democracy in case environments.

\begin{tabular}{llc}
\hline & \multicolumn{1}{c}{ Local direct democracy instruments } & $\begin{array}{c}\text { Direct democracy capacity } \\
\text { of local executive }\end{array}$ \\
\hline Italy & Laws $142 / 901990$ and $265 / 991999$ introduce for citizens popular \\
& initiatives, consultative and abrogative, and for the executive \\
& mandatory referendums regarding mergers of municipalities and \\
& changes of region; $50 \%$ turnout required. Rarely used. \\
Austria & Right for executive to initiate binding and non-binding referendums; for \\
& council, a recall referendum; and for citizens, an agenda initiative \\
& quorum: $20 \%$ of electorate. Rarely used: less than once per year across \\
& Austria since 1945 (Kersting \& Vetter, 2003, p. 128). \\
Switzerland & Three types: for governments, mandatory referendum, e.g., regarding \\
& budget, and for citizens, the optional referendum, with a quota $2.5-$ \\
& 20\% can force the submission of a government decision to a popular \\
& vote, and the initiative, with a quota $2.5-20 \%$ can propose a new bill \\
& to be submitted to a popular vote. Frequently used: on average 30 \\
& voting opportunities for a Swiss citizen each year (Kersting \& Vetter, \\
& 2003, p. 144).
\end{tabular}

Source: Kersting and Vetter (2003); Schiller (2017). 
To investigate the implementation of a 'populist democratic agenda', I explore the expression of the concepts of popular sovereignty and 'the people' by PRR parties in positions of local government leadership. I conduct a qualitative content analysis of three types of executive action: direct democratic instruments, their policies introduced more broadly, and their interactions with the council. Regarding the latter, the meetings of the council in Padua and Wels are analysed, with the executive chairing the meetings and able to propose resolutions; while in Thun, the government responses to council questions are analysed. The material used is outlined in Table 5. To compare between the cases, the institutional and political contexts are explored with the aid of expert interviews and secondary literature to determine the respective forms of local democracy.

\section{PRR Parties in Local Government: Consequences for Representative Democracy}

Before analysis of how these local government cases utilise the new opportunities to implement a populist democratic agenda, this section first outlines the systemic constraints each face. These are considered with reference to the electoral system, the form of the cabinet, and the resulting balance of power between the executive and the wider council (see Table 3).

The 1993 reforms to the Italian local government generated a new model of mayoral dominance (Baldini \& Legnante, 2000, p. 69; Magnier, 2004). Upon election in 2014,

Table 5. Government actions analysed in study.

\begin{tabular}{|c|c|c|c|}
\hline & $\begin{array}{l}\text { Direct and participatory democratic } \\
\text { methods }\end{array}$ & Local government policies & $\begin{array}{l}\text { Local government } \\
\text { interactions with council }\end{array}$ \\
\hline $\begin{array}{l}\text { Padua, Italy } \\
\text { Lega Nord mayor; } \\
\text { period analysed: } \\
\text { 2014-16 }\end{array}$ & $\begin{array}{l}\text { Proposed referendum on } \\
\text { intermunicipal } \\
\text { amalgamation(referenced in this } \\
\text { paper as PRef, May 2016). }\end{array}$ & $\begin{array}{l}\text { Emergency Ordinances } \\
\text { issued by mayor (PP, } \\
\text { 2014-16). }\end{array}$ & $\begin{array}{l}\text { Mayoral resolutions from } \\
\text { Padua council } \\
\text { meetings (PR, 2014- } \\
\text { 16). }\end{array}$ \\
\hline $\begin{array}{l}\text { Wels, Austria FPÖ } \\
\text { mayor; period } \\
\text { analysed: } 2015- \\
17\end{array}$ & Survey of citizens (WRef, Oct. 2016). & $\begin{array}{l}\text { Proposals publicised in } \\
\text { council newsletters } \\
\text { (WP, 2015-2017). }\end{array}$ & $\begin{array}{l}\text { FPO resolutions from } \\
\text { Wels council meetings } \\
\text { (WR, 2015-2017). }\end{array}$ \\
\hline $\begin{array}{l}\text { Thun, Switzerland } \\
\text { SVP mayor; period } \\
\text { analysed: } 2010-17\end{array}$ & $\begin{array}{l}\text { Multiple government-initiated } \\
\text { referendums (TRef, 2011-2018). }\end{array}$ & $\begin{array}{l}\text { Executive strategy } \\
\text { documents (TP, 2011, } \\
\text { 2015). }\end{array}$ & $\begin{array}{l}\text { Executive responses to } \\
\text { Thun council questions } \\
\text { (TR, 2011-2018). }\end{array}$ \\
\hline
\end{tabular}

the Lega Nord mayor in Padua gained personal responsibility over the appointment of the executive and was guaranteed a majority in the council. The relatively weak council body can only remove the mayor by dissolving itself and calling new elections. ${ }^{9}$ In order to secure support from the council, the executive members chosen included the centreright Forza Italia and far-right Fratelli d'Italia from the cross-party electoral coalition. In both Wels and Thun, the executive is instead formed via a process of proportional allocation. ${ }^{10}$ Following the 2015 Wels council election, the executive comprised four FPÖ members, three SPÖ (Social Democratic Party) and one ÖVP (People's Party). A formal coalition between the FPÖ and the ÖVP was agreed to achieve a working majority. As in the Italian system, Austrian mayors are dominant over local politics (Fallend, 2011, p. 20). In the Swiss case of Thun, the SVP gained the mayoral position as the biggest party with 12 of 
40 seats in the parliament and two of five in the executive (Schiess, 2010). Power is shared with the SP (Social Democratic Party) and BDP (Conservative Democratic Party) in a multi-party executive, as is typical at all levels of Swiss politics (Lijphart, 2012, p. 33). The mayor in this context is weak, and presides over a collegiate city government in a highly consensual form. The three cases therefore differ in the degree to which the governing PRR parties attained dominance over coalition partners and local government functioning as a product of the electoral systems.

\section{The Promotion of Popular Sovereignty by PRR Parties in Local Government}

Do these parties promote popular sovereignty within the established form of representative democracy once in government? The capacity for party actors to involve citizens in governance more directly depends upon the varying institutional openness of the setting (see Table 4). Analysis of the usage of varied direct democratic instruments by PRR government actors and their surrounding discourse provides insight into their different conceptions of the linkage between citizens and local government within these confines.

Italian local governments have been authorised to hold consultative referendums as a means of popular participation since a 1990 reform, along with other forms of public consultation (Council of Europe, 1993; Vesperini, 2009). ${ }^{11}$ In Padua, the PRR-led executive proposed just one referendum: to approve an administrate reform for the merger of nearby Ponte San Nicolò with its own municipality. ${ }^{12}$ The mayor justified his support for the measure in terms of the primacy of the will of the people:

Mayor Bitonci has already declared in favour [of the referendum], underlining how important it is, on these issues, to listen above all to what citizens want and how important it is to then give them the right tools to evaluate the facts. (Padova Oggi, 2016)

After two years of the full five-year term the mayor lost a vote of confidence, before this or any other referendums could be held. In a sense, this demonstrates how the horizontal autonomy of the 'strong mayor' within the reformed Italian system is not matched by sufficient resources to manage the complex relationships involved in urban governance (Magnier, 2003). More crucially, as expanded upon in the following section, this illustrates how the model of government in Padua was one of excessively personal control by a mayor in pursuit of nativist aims ideologically closer to his own PRR party than his centre-right coalition partners. Ultimately, this proved to be his downfall: a majority of the council including coalition partners Forza Italia accused the 'solitary leader' of betrayal of agreements in favour of governing alone (Custodero, 2016). Without recourse to participatory methods, the style of government was one that remained representative in character. Yet a shift towards plebiscitarianism is shown in the PRR mayor's pursuit of a personal linkage with citizens without mediation from party intermediaries, particularly by coalition partners.

Local governments in Upper Austria may initiate referendums, special assemblies and surveys (Bürgerbefragungen). However, these instruments of participatory and direct democracy are rarely used in a strongly representative environment (Eberhard, 2013). A year after the FPÖ gained power in Wels, they initiated their first experiment with popular participation via a survey of citizens on a package of proposed policies (WR Oct. 2016). 
The survey asked residents five questions: two regarding the expansion of public transport services, one on changes to road planning, one about a reduction in education costs and one about a reduction in spending on culture. Each of the questions was approved by a majority of voters, however at a very low level of turnout: just 6,000 voters, or $15 \%$ of the population. The extremely low turnout can be explained by the uncontentious topics, the structuration of the questions to ensure the preferred response, along with the lack of other higher-order elections held simultaneously to boost turnout. The FPÖ mayor nevertheless promised to execute the approved proposals and affirmed the survey was an expression of expanded popular sovereignty:

"There is always talk of direct democracy and civic participation. Here we have done just that". (Nowak, 2016)

Following accusations of improper use of citizen data by the government in the survey process, a local newspaper sympathetic to the PRR similarly defended the action as a challenge to the existing representative model:

Aloofness and lack of closeness to citizens are often mentioned when it comes to the bad image of politics. Because the Mayor wanted to fight against precisely that and ask his citizens about the development of the city, he is now attacked by the Data Protection Authority of Vienna! (Wochenblick, 2017)

The survey, along with other heavily circumscribed initiatives with minimal popular involvement, demonstrate a limited attempt by the FPÖ to expand popular participation in the decision-making process which does not increase responsiveness to citizen preferences nor impose control over the executive to a greater extent. ${ }^{13}$ In this exception to the continuing representative character of governance, we see elements of plebiscitarianism - that is, a more direct linkage being made between citizens and government, yet with the latter firmly in control of the process.

Instruments of direct democracy are famously well developed in Switzerland, with diverse forms and a high frequency of usage also found at the municipal level (Council of Europe, 1993; Kriesi \& Trechsel, 2008, p. 49; Trechsel \& Kriesi, 1996). In the canton of Bern, in which Thun is situated, local governments can submit mandatory referendums to the electorate for adoption and consultation but only in certain prescribed situations. More commonly, referendums are used by opposition parties to challenge government actions (Bützer, 2007, p. 222; Council of Europe, 1993, p. 51), and citizens may request referendums for proposals, or for the modification or abrogation of government proposals (Council of Europe, 1993, p. 49). The expansion of popular participation was a prominent aim of the SVP-led executive in Thun, as one of five legislative aims for the 2015-18 period (TP 2015). However, referendums have not been used to a greater extent than previously: seven were held during 2011-2017, the same as in the previous seven-year period prior to SVP leadership. The referendums of the local executive have been ideologically uncontentious in content: all have focused on matters of urban planning, with the exception of a partial revision to the city constitution in November 2013. ${ }^{14}$ Furthermore, the non-executive SVP councillors have not initiated any referendumsin line with their frequent opposition to migration related events in the town. Therefore the outcome of SVP participation in local government is not more of a participatory form than that of their predecessors, nor one that aims to challenge the status quo in terms of PRR 
ideological priorities. In fact, each of the three cases analysed seem to demonstrate themselves to be, as noted by Kaltwasser (2014, p. 484) of populists more generally, 'not against representation per se, but rather [wanting] to see their own representatives in power'. The cases vary in the degree to which a more direct link between their representatives and the people is promoted by the populist-led local governments: more so in the Italian and Austrian cases than the Swiss.

\section{The Definition of 'The People' by PRR Parties in Local Government}

How do these PRR parties define 'the people' whom they aim to represent in power? This section explores the ways in which their policies and surrounding discourse delimit the boundaries of local citizenship. Its demarcation along ethno-cultural lines is a fundamental ideological component of the PRR, yet one that is implemented and expressed to starkly varying degrees in these cases.

The increased power held by the mayor in the reformed Italian local government system has grown especially in two, previously unimportant, policy areas: social assistance and security (Magnier, 2004, p. 180). Security is a policy area in which local authorities possess significant responsibility since the introduction of mayor-issued emergency ordinances in 2008, which enable policy responses to their own defined threats (Ambrosini, 2013; Castelli Gattinara, 2016, p. 35). Furthermore it is a 'golden issue' of the PRR, located at the nexus of their key ideological tenets of authoritarianism, populism and nativism (Mudde, 2007). Like security, migration is another issue around which PRR parties mobilise the electorate, and a policy area over which Italian local governments have significant responsibility (Penninx, Kraal, Martiniello, \& Vertovec, 2004;Rogers \& Tillie, 2001). Prior analyses have shown the compatibility of these policy areas in the proliferation of security-oriented migration policy andmigrationoriented security policy (Caponio \& Graziano, 2011; Gilbert, 2009). Under the Lega Nord-led executive in Padua, a connection with migrants is explicitly stated in a number of security ordinances that aim to obstruct, displace, or even remove their claimed threatening presence from urban space entirely. ${ }^{15}$ In addition, a measure to obstruct public housing for non-Italians - the 'Paduans First' policy - resulted in $92 \%$ of public housing going to Italian citizens between March and September 2016, in comparison to 67\% between 2010 and 2012 (PP, Sep. 2016). As noted of urban migrationsecurity policies elsewhere, these actions not only serve to remind 'native' citizens of the threat faced from outsiders but also the primacy of their status in comparison (Ambrosini, 2013).

The FPÖ have also pursued a newly ethnocentric direction of policy in the local government of Wels. As well as the role of mayor, the FPÖ negotiated responsibility over the areas of integration and security, described throughout the campaign as the city's primary problems (Pachner, 2013). Plans were announced to restrict a number of welfare benefits to Austrian nationals (Rohrhofer, 2015) and ban the Islamic headscarf for public employees (Herzog, 2017). However, due to the Austrian local government lacking the necessary legal powers, neither measure was implemented. ${ }^{16}$ Nevertheless, the publicising of these intentions functions as a strategy of party positioning regarding the demarcation of local citizenship. Furthermore, the long campaign to resist the placement of refugee centres in Wels was defended in terms of the threat to the people posed by an already high 
foreign population in the city (WR Jan. 2016, Feb. 2016; WP Feb. 2016, May 2016). The mayor repeatedly publicised his opposition as follows:

The goal must continue to be closed as a city and to be united against the federal and regional governments in order to achieve the best possible result for Wels (WP Feb. 2016, May 2016). ${ }^{17}$

The concept of people as ethnos is also supported by the traditional ethno-cultural ideal presented in the new emphasis placed upon the folk festival Volksfest and German language culture in schools (WP Feb. 2017). Through these actions and the surrounding discourse, the FPÖ in Wels promote an antagonism with two groups - the political elites and those deemed to be outsiders in an ethno-cultural sense - in opposition to whom, the represented local and 'native' group can be more clearly constructed.

The governing actions of the SVP-led executive in Thun have not demonstrated the ethnocentric intentions of the other two cases. The government has used an inclusive discursive formulation of 'the people' distant from the characteristic ethnocentric approach of the SVP (Bernhard, Kriesi, \& Weber, 2015; Skenderovic, 2009). In the definition of the legislative aim of increased citizen participation, the executive outlines the following:

Thun is a diverse city. The executive wants to increase the use of the potential within the population. For this purpose, all generations and broad sections of the population should be involved. (TP 2015)

Non-executive party actors in the council nevertheless appear ideologically similar to the other cases examined in its nativism. This is shown by repeated questions to the executive from the SVP council representatives regarding migration and security, often in relation to resistance towards local refugee centres (TR Jun. 2011, Jun. 2013, Jan. 2016, Jun. 2016). The moderation of the responses from the SVP mayor reflects a distance between the party in the executive and the council. While the council representatives remain 'responsive' to migration issues and follow the ethnocentric party line, the local executive performs a 'responsible' administrative role and employ more pluralist framing of citizenship. Such a defence of executive decisions and programmes in opposition to their own representatives has previously been observed from other Swiss local government actors (Mcdonnell \& Mazzoleni, 2014). This hybrid 'one foot in, one foot out of government' strategy has also been observed with PRR parties in national government (Albertazzi \& Mcdonnell, 2005; Bernhard et al., 2015; Zaslove, 2012). In contrast with Mair's (2011, p. 14) influential idea of a contemporary division of labour between 'responsive' populist parties in opposition and 'responsible' mainstream parties in government, PRR parties are able to enact this division in office themselves with their own executive and parliamentary actors.

Cross-National Variations in the Consequences of PRR Parties in Local Government for Local Representative Democracy

Systems that allocate more personal control of local government to mayors have been theorised to lead to a mayoral preference for a more direct linkage between themselves and citizens, including through measures that weaken the role of the council (Haus \& 
Sweeting, 2006; Heinelt \& Hlepas, 2006). Furthermore, a recent cross-European survey of mayors found greater support for participatory as opposed to representative forms of government among figures in a 'strong-mayor' role compared to the weaker 'committeeleader' role (Vetter, Heinelt, \& Rose, 2018, p. 195). These cases demonstrate little evidence of an intensification of participatory methods of governance, regardless of the institutional setting. However, change to the existing representative principle is witnessed in the more direct linkage envisaged between the executive and the citizens in the cases of Padua and Wels. In the bypassing of intermediary institutions, while maintaining executive control over the procedure, these local governments have shown elements of plebiscitarianism.

Table 6. Relation between form of local democracy and democratic agenda of PRR-led local government.

\begin{tabular}{|c|c|c|c|c|}
\hline & \multicolumn{2}{|c|}{ Local executive autonomy } & \multicolumn{2}{|c|}{$\begin{array}{c}\text { Democratic agenda promoted by PRR-led local } \\
\text { government }\end{array}$} \\
\hline & $\begin{array}{l}\text { Majoritarian form } \\
\text { of democracy }\end{array}$ & $\begin{array}{l}\text { Direct democracy } \\
\text { capacity of local } \\
\text { executive }\end{array}$ & Democratic form & $\begin{array}{l}\text { Definition of } \\
\text { 'the people' }\end{array}$ \\
\hline $\begin{array}{lr}\text { Padua, } & \text { Italy } \\
\text { Lega } & \text { Nord } \\
\text { mayor } & 2014- \\
16 . & \end{array}$ & + & - & $\begin{array}{l}\text { Representative (leader-focused) } \\
\text { with plebiscitarian elements }\end{array}$ & Nativist ++ \\
\hline $\begin{array}{l}\text { Wels, Austria } \\
\text { FPÖ mayor } \\
2015-.\end{array}$ & $+/-$ & + & $\begin{array}{l}\text { Representative } \\
\text { (executivefocused) with } \\
\text { plebiscitarian elements }\end{array}$ & Nativist + \\
\hline $\begin{array}{l}\text { Thun, Switzerland } \\
\text { SVP mayor } \\
2010-\text {. }\end{array}$ & - & - & $\begin{array}{l}\text { Representative } \\
\quad \text { (coalitionfocused) }\end{array}$ & Pluralist \\
\hline
\end{tabular}

The most conspicuous change resulting from PRR control of local government dependent upon the institutional setting - is in nativist policy output. Specifically, higher executive autonomy is associated with a stronger emphasis upon exclusionary nativism in PRR party-led local government output. With greater personal control and resulting capacity for ideological direction, the mayors in Wels and in particular Padua have focused upon a 'performance of crisis', precipitated by migration and manifested in localised security risk (Moffitt, 2015; Paxton, 2019). In contrast, the distinctively moderate governing style of the PRR in Thun, despite the radical discourse of their non-executive council members, is related to the constraints faced by parties within the Swiss system of power-sharing. As defined by Lijphart (2012), consensus democracies have a less abrasive political culture, and more functional business-like proceedings due to the multiparty, proportional system. Prior studies of the SVP have shown their high level of populism during periods of opposition and (election and direct-democratic) campaigns decreases when in government (Bernhard, 2017; Bernhard et al., 2015). The findings from Thun suggest the SVP tends to display a decidedly non-populist, rather managerial approach, in the municipal, as well as cantonal and federal, levels of government. This study expands on past research to show that while nativism may be subdued among executive members, it is retained among the council representatives. An outline of the proposed relation 
between the local democratic form and the extent of the populist democratic agenda promoted by the PRR-led local governments is displayed in Table 6 .

\section{Conclusion}

PRR parties have challenged representative democracy with persistent calls for the introduction and increased use of direct democracy (Mudde, 2007, p. 152; ; Taggart, 2004). This article is the first to explore the extent to which such claims are implemented from positions of power in local government. Scarce evidence of a 'participatory turn' is found, regardless of the extent of opportunities offered in this arena. However, two sets of changes are evident in their actions that demonstrate a distinctive conception of representative democracy, more so when less constrained by the necessary of compromise with other parties. Firstly, in a more direct linkage envisaged between the executive and the citizens, characterised here as elements of plebiscitarianism. And secondly, in efforts to redefine 'the people' in nativist terms. This exploratory study suggests the democratic consequences of PRR party participation in local government are shaped by the relative strength of the executive within the political system: specifically, whether party actors are constrained within a consensual political system or freer to implement policy independently in more majoritarian systems.

Studies of the consequences of populist parties for representative democracy must be careful to identify the contribution made by populism in isolation from their other ideological traits (Pappas, 2016, 2018; Rydgren, 2017; Stavrakakis, Katsambekis, Nikisianis, Kioupkiolis, \& Siomos, 2017). The principal consequences posed by these PRR-led government actions for local representative democracy derive from their attempted resolution of the democratic boundary problem through an ethnically exclusionary formulation of the citizen; in other words, their higher degree of nativism. What is the contribution of populism to the democratic agenda in these cases? There are elements of a strengthening of the plebiscitarian idea of a more direct linkage between executive and citizen, but very little evidence of attempts to expand popular sovereignty through participatory interventions to rebalance the representative-direct democratic form. The remaining key ideological tenets of populism - people-centrism and anti-elitism might be better conceptualised in these cases as discursive strategies through which the radical right ideology is advanced, rather than the most pertinent features to define these - fundamentally 'radical right', rather than populist-parties (Aslanidis, 2015; Rydgren, 2017).

Recent research on the policy influence and stability of populist parties in national government has refuted earlier accounts of these parties being 'doomed to fail' in power (Albertazzi \& Mcdonnell, 2015; Zaslove, 2012). The local level of government offers expanded opportunities for investigation of the conditions for their degree of impact when in office. Future research should systematically test the hypotheses generated by these findings through expanded cross-country analyses, while following the strategy of varying cases according to the institutional form of local democracy and resulting executive autonomy. To isolate the contribution made by populism aside from the host party ideologies, cases of the populist left and centre in the leadership of local government should also be included. In so doing, future studies can evaluate and build upon this 
exploratory analysis of PRR governing practice to investigate whether and how local government functions as a laboratory for populist experimentation in democracy.

\section{Notes}

1. The idea of PRR parties using local government as a laboratory for policy experimentation is a common trope in press coverage (examples include: Kapeller, 2016; Chrisafis, 2015; Chassany, 2017).

2. The strongest advocacy for participatory politics originated from New Left and green partysupporters with a grounding in post-materialist values (Inglehart, 1977, 1990); rightwing populists of the 'silent counter-revolution' rather desire more effective and responsive leadership, at least in part due to a more authoritarian set of values (Ignazi, 1992; Mudde, 2004, p. 558; Taggart, 2004).

3. In contrast, populist left parties are more likely to distinguish 'the people' based on class (Mudde \& Kaltwasser, 2013), while a 'purely populist' party like the Five Star Movement has attempted to create a homogenous entity without any qualifications (Manucci \& Amsler, 2018).

4. For a rare example of a study that focuses on the influence of structural factors on populist parties in government, see: Zaslove (2012).

5. It should be noted that the level of dissatisfaction with local representative democracy, as measured through for instance local electoral turnout and trust in local government (John, 2001; Le Galès, 2002), in fact varies greatly across Europe.

6. Local government output-legitimacy, on the other hand, has been addressed through administrative reforms to improve the efficacy of policy-outcomes via municipal amalgamations, decentralisation of power and other reforms labelled as 'New Public Management' (Osborne \& Gaebler, 1992).

7. The interest groups variable used by Lijphart (2012) is excluded from this study due to the minimal amount of evidence available for this activity in governance of small and mediumsized cities.

8. The other variables used by Lijphart (2012) but excluded from this study as unhelpful are: unicameral vs. bicameral legislature, the flexibility of the constitution, the presence of judicial review, and the independence of the central bank.

9. Such a dissolution actually occurred in Padua in October 2016: a rare event in local Italianpolitics.

10. In Wels, there are separate mayoral and council elections, the latter from which members ofthe executive are then proportionately drawn. In Thun, the executive and council are proportionately allocated through separate elections.

11. Such referendums have famously led to the banning of cars from the city centre in severalmajor Italian cities (Bobbio, 2005, p. 44).

12. The merger of small municipalities has been an important subject in plans to improve localgovernment service delivery and output-legitimacy, and requires a referendum in Italy (Hulst \& Montfort, 2007; Swianiewicz, 2010).

13. Other smaller scale examples of participatory governance initiatives in Wels include a (currently inactive) internet application 'Mach Mit' and a security consultation held in a local sauna (Nowak, 2017).

14. According to the amendment, the objectives set by the executive in Thun would no longerrequire approval by the Legislative Body but just submission for information. Similar constitutional reforms were proposed, and passed, in 2005 and 2001.

15. The ordinances that specify the security threat posed by migrants are prohibitions on prostitution (PP Apr. 2014; Feb. 2015) and vehicles for sleeping (PP Jul. 2015), and ones that legislate for health checks on arrivals from Africa (PP Nov. 2014) and hygiene checks on municipal housing (PP 2015). 
16. An 'anti-face-veiling act' was later passed by the national government in October 2017.

17. Changes in the relations between the Wels local government and the Austrian federal government following the ascension to national power of the FPÖ after the 2018 Federal Election lie beyond the timescale of this study.

\section{References}

Albertazzi, D., \& Mcdonnell, D. (2005). The Lega Nord in the second Berlusconi government: In a league of its own. West European Politics, 28, 952-972.

Albertazzi, D., \& Mcdonnell, D. (Eds.). (2008). Twenty-first century populism. London: Palgrave Macmillan UK.

Albertazzi, D., \& Mcdonnell, D. (2015). Populists in power. Abingdon: Routledge.

Almeida, D. (2017). Cultural retaliation: The cultural policies of the 'new' Front national. International Journal of Cultural Policy, 1-3.

Ambrosini, M. (2013). 'We are against a multi-ethnic society': Policies of exclusion at the urban level in Italy. Ethnic and Racial Studies, 36, 136-155.

Aslanidis, P. (2015). Is populism an ideology? A refutation and a new perspective: Is populism an ideology? Political Studies, 64, 88-104.

Baldini, G., \& Legnante, G. (2000). Città al voto: I sindaci e le elezioni comunali. Bologna: Il Mulino.

Barney, D. D., \& Laycock, D. (1999). Right-populists and plebiscitary politics in Canada. Party Politics, 5, 317-339.

Barr, R. R. (2009). Populists, outsiders and anti-establishment politics. Party Politics, 15, 29-48.

Bernhard, L. (2017). Three faces of populism in current Switzerland: Comparing the populist communication of the Swiss people's party, the Ticino League, and the Geneva citizens' Movement. Swiss Political Science Review, 23, 509-525.

Bernhard, L., Kriesi, H., \& Weber, E. (2015). The populist discourse of the Swiss people's party. In H. Kriesi, \& T. S. Pappas (Eds.), European populism in the shadow of the great recession (pp. 125- 139). Colchester: ECPR Press.

Bobbio, L. (2003). Building social capital through democratic deliberation: The rise of deliberative arenas. Social Epistemology, 17, 343-357.

Bobbio, L. (2005). Italy: After the storm. In B. Denters \& L. E. Rose (Eds.), Comparing local governance: Trends and developments (pp. 29-46). Basingstoke: Palgrave.

Bolin, N., Lidén, G., \& Nyhlén, J. (2014). Do anti-immigration parties Matter? The case of the Sweden democrats and local refugee policy. Scandinavian Political Studies, 37, 323-343.

Bowler, S., Denemark, D., Donovan, T., \& Mcdonnell, D. (2016). Right-wing populist party supporters: Dissatisfied but not direct democrats. European Journal of Political Research, 56, 70-91.

Bowler, S., Donovan, T., \& Karp, J. A. (2002). When might institutions change? Elite support for direct democracy in three nations. Political Research Quarterly, 55, 731-754.

Bützer, M. (2007). Civic engagement and uncontrolled ballot votes: Evidence from Swiss cities. Local Government Studies, 33, 215-236.

Canovan, M. (1999). Trust the people! populism and the two faces of democracy. Political Studies, 47, 2-16.

Canovan, M. (2002). Taking politics to the people: Populism as the ideology of democracy. In Y. Mény, \& Y. Surel (Eds.), Democracies and the populist challenge (pp. 25-44). Basingstoke: Palgrave.

Caponio, T., \& Graziano, P. (2011). Towards a security-oriented migration policy model? Evidence from the Italian case. In E. Carmel, A. Cerami, \& T. Papadopoulos (Eds.), Migration and welfare in the New Europe: Social protection and the challenges of integration (pp. 105-120). Bristol: Policy Press. 
Caramani, D. (2017). Will vs. Reason: The populist and technocratic forms of political representation and their critique to party government. American Political Science Review, 111, 54-67.

Castanho Silva, B. (2017). Contemporary populism: Actors, causes, and consequences across 28 democracies (Doctoral thesis). Central European University.

Castelli Gattinara, P. (2016). The politics of migration in Italy: Perspectives on local debates and party competition. Abingdon: Routledge.

Caulfield, J., \& Larsen, H. O. (2002). Local government at the millennium. Wiesbaden: Springer Fachmedien.

Chassany, A-S. (2017). The French town that shows how Marine Le Pen could win. Financial Times. Retrieved from https://www.ft.com/content/309292d4-1a28-11e7-a266-12672483791a.

Chrisafis, A. (2015). Talk of the town: French Mayor's "Laboratory of the Far Right." The Guardian. Retrieved from http://www.theguardian.com/world/2015/aug/29/french-mayorbeziers-accused -oflaboratory-of-the-far-right.

Copus, C. (2003). Local government reform: Introducing a new set of political dynamics. Representation, 39, 119-128.

Council of Europe. (1985). European charter of local self-government. Strasbourg: Council of Europe.

Council of Europe. (1993). Local referendums: Report Prepared by the steering committee on local and regional authorities CDLR. For the 10th Conference of European Ministers responsible for local government, The Hague, 15-16 September 1993 / Council of Europe. Steering Committee on Local and Regional Authorities. Council of Europe.

Custodero, A. (2016). Dimissioni Di Massa a Padova, Cade La Giunta Del Leghista Bitonci Cronaca. Il Mattino di Padova. Retrieved from http://mattinopadova.gelocal.it/padova/ cronaca/2016/11/12/news/dimissioni-dimassa-a-padova-cade-la-giunta-del-leghista-bitonci-1.1 4398279.

DiGaetano, A., \& Strom, E. (2003). Comparative urban governance: An integrated approach. Urban Affairs Review, 38(3), 356-395.

Eberhard, H. (2013). Austria - municipalities as the "third Tier" of Austrian Federalism. In C. Panara, \& M. R. Varney (Eds.), Local government in Europe: The 'fourth level' in the EU multilayered system of governance (pp. 1-25). London: Routledge.

Egner, B., Gendźwiłł, A., Swianiewicz, P., \& Pleschberger, W. (2018). Mayors and political parties. In H. Heinelt, A. Magnier, M. Cabria, \& H. Reynaert (Eds.), Political leaders and changing local democracy (pp. 327-359). London: Palgrave Macmillan.

Ennser, L. (2012). The homogeneity of West European party families: The radical right in comparative perspective. Party Politics, 18, 151-171.

Fallend, F. (2011). Austria: From consensus to Competition and participation? In F. Hendriks, A. Lidström, \& J. Loughlin (Eds.), The Oxford handbook of local and regional democracy in Europe (pp. 173-196). Oxford: University Press.

Gilbert, L. (2009). Immigration as local politics: Re-bordering immigration and multiculturalism through deterrence and incapacitation. International Journal of Urban and Regional Research, 33, 26-42.

Haus, M., \& Sweeting, D. (2006). Mayors, citizens and local democracy. In Henry Bäck, Hubert Heinelt, \& Annick Magnier (Eds.), The European mayor: Political leaders in the changing context of local democracy, urban and regional research international (pp. 151-176). Wiesbaden: VS Verlag für Sozialwissenschaften.

Heinelt, H., \& Hlepas, N-K. (2006). Typologies of local government systems. In The European Mayor, VS Verlag für Sozialwissenschaften. Retrieved from https://link.springer.com/chapter/ 10.1007/978-3-531-90005-6_2.

Hendriks, F. (2010). Vital democracy: A theory of democracy in action. Oxford: Oxford University Press. 
Hendriks, F., Loughlin, J., \& Lidström, A. (2010). European subnational democracy: Comparative reflections and conclusions. In F. Hendriks, A. Lidström, \& J. Loughlin (Eds.), The Oxford handbook of local and regional democracy in Europe (pp. 715-743). Oxford: Oxford University Press.

Herzog, P. (2017). Integrationsreferent Kroiß will Kopftücher vom Magistrat verbannen. Bezirks Rundschau. Retrieved from https://www.meinbezirk.at/wels-welsland/politik/integrationsrefer ent-kroiss-will-kopftuecher-vom-magistrat-verbannend1996863.html.

Hug, S. (2004). Occurrence and policy consequences of referendums: A theoretical model and empirical evidence. Journal of Theoretical Politics, 16, 321-356.

Hug, S., \& Tsebelis, G. (2002). Veto players and referendums around the world. Journal of Theoretical Politics, 14, 465-515.

Hulst, R., \& Montfort, A. V. (Eds.). (2007). Inter-municipal cooperation in Europe. Dordrecht: Springer Netherlands.

Ignazi, P. 1992. The silent counter-revolution. European Journal of Political Research 22 (1): 3-34. Inglehart, R. (1977). The silent revolution. Princeton: Princeton University Press.

Inglehart, R. (1990). Culture shift in advanced industrial society. Princeton: Princeton University Press.

Ivarsflaten, E. (2008). What unites right-wing populists in Western Europe?: Re-examining

grievance mobilization models in seven successful cases. Comparative Political Studies, 41, 3-23.

John, P. (2001). Local governance in Western Europe. London: SAGE.

Kaltwasser, C. R. (2014). The responses of populism to Dahl's democratic dilemmas. Political Studies, 62, 470-487.

Kapeller, L. (2016). FPÖ: Die blaue Musterstadt. Die Zeit. Retrieved from https://www.zeit.de/2016/38/fpoe-wels-buergermeister-andreas-rabl.

Kersting, N., \& Vetter, A. (Eds.). (2003). Reforming local government in Europe. Wiesbaden: VS Verlag für Sozialwissenschaften.

Kriesi, H., \& Trechsel, A. H. (2008). The politics of Switzerland: Continuity and change in a consensus democracy. Cambridge: Cambridge University Press.

Laclau, E. (1977). Politics and ideology in Marxist theory: Capitalism, fascism, populism. London: New Left Books.

Le Galès, P. (2002). European cities: Social conflicts and governance. Oxford: Oxford University Press.

Lijphart, A. (2012). Patterns of democracy: Government forms and performance in thirty-six countries (2nd ed). New Haven: Yale University Press.

Loughlin, J., Hendriks, F., \& Lidström, A. (Eds.). (2011). The Oxford handbook of local and regional democracy in Europe. Oxford: Oxford University Press.

Luthardt, W. (1994). Direkte Demokratie: Ein Vergleich in Westeuropa. Baden-Baden: Nomos.

Magnier, A. (2003). Subsidiarity: Fall or premise of "local government reforms". The Italian case. In N. Kersting, \& A. Vetter (Eds.), Reforming local government in Europe (pp. 183-197). Wiesbaden: VS Verlag für Sozialwissenschaften.

Magnier, A. (2004). Between institutional learning and re-legitimization: Italian mayors in the unending reform. International Journal of Urban and Regional Research, 28, 166-182.

Magnier, A. (2005). European local government reforms and cultures of political representation. In H. Reynaert, K. Steyvers, P. Delwit, \& J.-B. Pilet (Eds.), Revolution or renovation? Reforming local politics in Europe (pp. 289-313). Brugge: Vanden Broele.

Mair, P. (2002). Populist democracy vs party democracy. In Y. Meny, \& Y. Sorel (Eds.), Democracies and the populist challenge (pp. 81-98). London: Palgrave Macmillan.

Mair, P. (2011). Bini Smaghi vs. The Parties: Representative government and institutional constraints, EUI Working Paper, RSCAS 2011/22.

Manucci, L., \& Amsler, M. (2018). Where the wind blows: Five star movement's populism, direct democracy and ideological flexibility. Italian Political Science Review / Rivista Italiana di Scienza Politica, 48, 109-132. 
Mcdonnell, D., \& Mazzoleni, O. (2014). Directly elected mayors and their parties: The cases of Genoa and Lausanne. Government and Opposition, 49, 92-119.

Meny, Y., \& Surel, Y. (2000). Par Le Peuple, Pour Le Peuple. Le Populisme Et Les démocraties. Paris: Fayard.

Meny, Y., \& Surel, Y. (2002). The constitutive ambiguity of populism. In Y. Meny, \& Y. Sorel (Eds.), Democracies and the populist challenge (pp. 1-21). London: Palgrave Macmillan.

Minkenberg, M. (2001). The radical right in public office: Agenda-setting and policy effects. West European Politics, 24, 1-21.

Moffitt, Benjamin. (2015). How to perform crisis: A model for understanding the key role of crisis in contemporary populism. Government and Opposition, 50(2), 189-217. doi:10.1017/gov.2014.13.

Moffitt, B., \& Tormey, S. (2014). Rethinking populism: Politics, mediatisation and political style: Rethinking populism. Political Studies, 62, 381-397.

Mouritzen, P. E., \& Svara, J. H. (2002). Leadership at the apex: Politicians and administrators in western local governments. Pittsburgh: University of Pittsburgh Press.

Mudde, C. (2004). The populist zeitgeist. Government and Opposition, 39, 541-563.

Mudde, C. (2007). Populist radical right parties in Europe. Cambridge: Cambridge University

Press.

Mudde, C., \& Kaltwasser, C. R. (2013). Exclusionary vs. Inclusionary populism: Comparing contemporary Europe and Latin America. Government and Opposition, 48, 147-174.

Nowak, G. (2016). Für uns ist das Ergebnis ein klares Votum. Tips. Retrieved from https:/www.tips. at/news/wels/wirtschaft-politik/374142-fuer-uns-ist-das-ergebnisein-klaresvotum.

Nowak, G. (2017). Keine heiße Luft, aber viele kleine Dinge bei der Sauna-Sprechstunde. Tips Online. Retrieved from https:/www.tips.at/news/wels/landleute/384516-keine-heisse-luftaberviele-kleine-dinge-bei-der-sauna-sprechstunde.

Osborne, D., \& Gaebler, T. (1992). Reinventing government: How the entrepreneurial spirit is transforming the public Sector. Reading, MA: Addison-Wesley.

Pachner, J. (2013). Welser Politstreit Nach Schlechten Noten in Bezirks-Vergleich. Kurier. Retrieved from https://kurier.at/chronik/oberoesterreich/politstreit-in-wels-nachschlechten-not en-in-bezirks-vergleich/23.333.910.

Padova, O. (2016). Bitonci: "Referendum per far scegliere a Ponte San Nicolò di fondersi con Padova." Retrieved from http://www.padovaoggi.it/politica/fusione-comuni-padovapontesannicolo-bitonci-referendum.html.

Pappas, T. S. (2016). Distinguishing liberal democracy's challengers. Journal of Democracy, 27, 22-36. Pappas, T. S. (2018). How to tell nativists from populists. Journal of Democracy, 29, 148152.

Pauwels, T. (2014). Populism in Western Europe: Comparing Belgium, Germany and The Netherlands. Abingdon: Routledge.

Paxton, F. (2019). The populist performance of Urban crisis: The policy influence of radical right populist parties in leadership of local government in Austria and Italy. In Benjamin Biard, Laurent Bernhard, \& Hans-Georg Betz (Eds.), Do they make a difference? The policy influence of radical right populist parties in Western Europe (pp. 123-144). Colchester: ECPR Press.

Penninx, R., Kraal, K., Martiniello, M., \& Vertovec, S. (2004). Citizenship in European cities. Immigrants, local politics and integration policies. Aldershot: Ashgate.

Pitkin, H. F. 1967. The concept of representation. Berkeley: University of California Press.

Rogers, A., \& Tillie, J. (2001). Multicultural policies and Modes of citizenship in European cities. Aldershot: Ashgate.

Rohrhofer, M. (2015). Welser Bürgermeister Will Sozialleistungen Für Nicht-EU Bürger Streichen. Der Standard. Retrieved from https://derstandard.at/2000024000669/WelserBuergermeisterwill-Sozialleistungenfuer-Nicht-EU-Buerger-streichen. 
Rydgren, J. (2017). Radical right-wing parties in Europe: What's populism got to do with it? Journal of Language and Politics, 16, 485-496.

Saward, M. (2006). The representative Claim. Contemporary Political Theory, 5, 297-318.

Scarrow, S. E. (2001). Direct democracy and institutional change: A comparative investigation. Comparative Political Studies, 34, 651-665.

Scarrow, S. E. (2003). Making elections more direct? Reducing the role of parties in elections. In B. E. Cain, R. J. Dalton, \& S. E. Scarrow (Eds.), Democracy tansformed? Expanding political opportunities in advanced Industrial democracies (pp. 44-58). Oxford: Oxford University Press.

Schiess, M. (2010). SP verzichtet: Raphael Lanz ist Thuns neuer Stadtpräsident. Der Bund. Retrieved from https://www.derbund.ch/bern/stadt/SP-verzichtet-Raphael-Lanz-ist-Thunsneuer-Stadtpr aesident-/story/10683025.

Schiller, T. (2011). Local direct democracy in Europe. Berlin: Springer Science \& Business Media.

Schiller, T. (2017). Local referendums: A comparative assessment of forms and practice. In L. Morel \& M. Qvortrup (Eds.), The Routledge handbook to referendums and direct democracy (pp. 60-80). Abingdon: Routledge.

Schmidt, M. G. (1996). When parties matter: A review of the possibilities and limits of partisan influence on public policy. European Journal of Political Research, 30, 155-183.

Shills, E. (1956). The torment of secrecy: The background and consequences of American security policy. London: Heinemann.

Skenderovic, D. (2009). The radical right in Switzerland: Continuity and change, 1945-2000. Oxford: Berghahn Books.

Smith, J. (2016). David Cameron's EU renegotiation and referendum pledge: A case of déjà Vu? British Politics, 11, 324-346.

Stanley, B. (2008). The thin ideology of populism. Journal of Political Ideologies, 13, 95-110.

Stavrakakis, Y., Katsambekis, G., Nikisianis, N., Kioupkiolis, A., \& Siomos, T. (2017). Extreme rightwing populism in Europe: Revisiting a reified association. Critical Discourse Studies, 14, 420-439.

Swianiewicz, P. (2010). If territorial fragmentation is a problem, is amalgamation a solution? An East European perspective. Local Government Studies, 36, 183-203.

Taggart, P. (2004). Populism and representative politics in contemporary Europe. Journal of Political Ideologies, 9, 269-288.

Trechsel, A. H., \& Kriesi, H. (1996). Switzerland: The referendum and initiative as a centrepiece of the political system. In P. V. Uleri, \& M. Gallagher (Eds.), The referendum experience in Europe (pp. 185-208). London: Palgrave Macmillan.

Urbinati, N. (2014). Democracy disfigured. Cambridge, MA: Harvard University Press.

Van Ostaijen, M., \& Scholten, P. (2014). Policy populism? Political populism and Migrant integration policies in Rotterdam and Amsterdam. Comparative European Politics, 12, 680-699.

Vatter, A. (2003). Consensus and direct democracy: Conceptual and empirical linkages. European Journal of Political Research, 38, 171-192.

Vatter, A. (2009). Lijphart expanded: Three Dimensions of democracy in advanced OECD countries? European Political Science Review, 1, 125-154.

Vatter, A., \& Bernauer, J. (2009). The missing dimension of democracy: Institutional patterns in 25 EU member states between 1997 and 2006. European Union Politics, 10, 335-359.

Vesperini, G. (2009). Regional and local government in Italy: An overview.

Vetter, A., Heinelt, H., \& Rose, L. E. (2018). Mayors' notions of local democracy. In H. Heinelt, A. Magnier, M. Cabria, \& H. Reynaert (Eds.), Political leaders and changing local democracy (pp. 173-209). London: Palgrave Macmillan.

Webb, P. (2013). Who is willing to participate? Dissatisfied democrats, stealth democrats and populists in the United Kingdom. European Journal of Political Research, 52(6), 747-772.

Whelan, F. G. (1983). Prologue: Democratic theory and the boundary problem. Nomos, 25, 13-47.

Wilks-Heeg, S. (2010). A slow and painful death? Political parties and local democracy in two Northern Towns. Local Government Studies, 36, 381-399. 
Wochenblick. (2017). Wird Welser Bürgermeister jetzt für direkte Demokratie bestraft? Retrieved from https://www.wochenblick.at/wird-welser-buergermeister-jetzt-fuerdirekte-demokratiebestraft/.

Zaslove, A. (2012). The populist radical right in government: The structure and agency of success and failure. Comparative European Politics, 10, 421-448. 